\title{
Voz e musicalidade na formação do ator
}

\author{
Fabio C. M. Cintra
}

\section{Técnica vocal ou atitude vocal?}

pensamento contemporâneo sobre natureza do trabalho do ator não admite que se conceba a função vocal separada da totalidade da atuação. $\mathrm{O}$ ator em ação presentifica, a cada instante, constructos complexos em que estão em jogo (mais que em movimento) seu corpo e seus sons, num espaço determinado. A idéia de que o ator realiza ações completas é, portanto, o ponto de partida para refletirmos sobre sua ação vocal.

A ação vocal, pensada como elemento integrante de cada momento da atuação, está subordinada à forma pela qual o corpo se organiza para executar uma ação específica. Essa ação vocal nasce de um impulso único, particular, diferenciado, é elemento integrante do gesto do ator como um todo. Logo, é impossível estabelecer uma forma única para abordá-la.

No entanto, $o$ ator precisa conhecer e usar a voz adequadamente, dentro de suas possibilidades, adquirindo fluência no uso da voz em todas as situações com as quais se defronta.

A abordagem tradicional da voz no teatro estabeleceu determinadas rotinas de exercícios que funcionam como portas de entrada para essa fluência, à maneira de treinamento. A tendência, no entanto, é transformar essas ro- tinas em estruturas fechadas, que limitam ou impedem usos diferenciados da função vocal.

Para que essas limitações não aconteçam, o ator deve ampliar e acumular competências vocais, de modo a constituir um corpo de conhecimento de característica plural, espontânea e diversificada, chegando a construir um repertório vasto de experiências sobre recursos corporais e vocais.

Isso significa conhecer o aparelho vocal e suas possibilidades, somar experiências diversas no plano da atuação, que exijam diferentes maneiras de utilização da voz. Significa explorar, experimentar e inventar com a voz.

A partir do questionamento e da formulação do problema apresentado por cada situação, o ator definirá o objetivo da atuação, o qual vai guiá-lo na elaboração de exercícios e na escolha de uma forma determinada de atuação vocal.

Mais que uma partitura definida com precisão, pensa-se aqui em uma série de atitudes vocais que definirão sonoridades, ritmos, timbres. É um repertório sonoro corporificado, que deverá vir à tona espontaneamente, no decorrer do desempenho, e cuja precisão poderá ser regulada de acordo com as necessidades. Mas esse repertório deve, de alguma forma, estar articulado para que possa ser compreendido como parte da composição do ator.

Fabio C. M. Cintra é professor do Departamento de Artes Cênicas da USP. 


\section{Respiração e memória muscular (importância das relações espaciais)}

A base física dessa produção vocal é a respiração. Ela apóia ritmicamente a ação, é a fonte de energia e sustentação temporal do ator. Ao lado da memória muscular, termo cunhado por Dalcroze, e das relaçóes com o espaço, a respiração configura o registro corporal dinâmico que possibilita a fluência da atuação.

$\mathrm{O}$ ator deve considerar como atividades cotidianas de seu ofício, entre muitas outras, o estudo das bases físicas do funcionamento da voz; o treinamento da memória rítmica muscular, através da qual se pode chegar a um corpo musicalizado; a prática musical através do canto e, se possível, de um instrumento; a prática da dança e, finalmente, a pesquisa, conformando o que poderíamos nomear uma técnica para que adquira a autonomia de encontrar seus caminhos para o desenvolvimento da musicalidade de sua atuação vocal.

O trabalho do ator demanda a criação de exercícios próprios. Mas esses exercícios podem ultrapassar o âmbito da produção e da emissão vocais, e adentrar o terreno da música; podem passar a considerar, como objetivo, a composição do plano sonoro de sua atuação em bases musicais.

\section{A música como matriz do procedimento vocal do ator}

O recurso a termos musicais, como composição, costuma ser recorrente nos textos sobre o ator.

Muitos dos procedimentos aqui descritos aproximam-se daqueles do músico que improvisa. $\mathrm{O}$ jogo da improvisação musical com o material sonoro, com o silêncio e com o tempo, configurando gestos e idéias musicais, guarda uma similaridade estrutural com o jogo do ator - e é nessa interseção que a música pode ser tomada, então, como uma matriz de referência possível para a pesquisa e o aprendizado vocal do ator. A música enquanto referência de linguagem, de articulação e composição, e não apenas a idéia de melodia, ou uma vaga definição de ritmo. Isso implica familiarizar o ator com a linguagem e os modos de ação da música, em especial da música improvisada.

\section{Linguagem musical}

A linguagem musical tornar-se-á então um recurso estrutural para a composição. A prática musical é, em si, a forma de apropriação desse pensamento estrutural. Ela leva à compreensão de que a música necessita uma composição, uma configuração determinada de som e silêncio, uma organização interna.

A improvisação é, dentre as práticas musicais, a que mais se relaciona com os procedimentos de aprendizado e criação do ator, por sua natureza ligada ao aqui-agora, assim como a do jogo teatral.

A improvisação musical pode atuar tanto como prática didática para a apropriação de conceitos musicais (dos básicos aos mais avançados), como para a experimentação e a criação musical.

$\mathrm{Na}$ relação com o trabalho do ator, podese chegar a elaborar atividades que intercambiem características comuns ao jogo de improvisação teatral e o musical, estabelecendo-se um campo de interseçôes extremamente rico, no qual a abordagem musical pode vir a transformar-se em instrumento importante para a criação.

\section{Canto coral como estratégia para a musicalização no teatro}

A partir dessa visão, o canto coral pode ser considerado uma prática musical adequada aos objetivos descritos. A prática do canto em conjunto tem atuado como fator importante na educação musical em todo o mundo.

A música coral é portadora de toda a tradição musical ocidental (isto é, nossa tradição musical), o que quer dizer que através de sua 
prática é possível entrar em contato e apreender formas históricas de organização e funcionamento do discurso sonoro.

Ela também se caracteriza por ser, provavelmente, a maneira mais fácil de o músico amador (caso da grande maioria dos estudantes de Artes Cênicas no país) entrar em contato com os conceitos e mecanismos básicos da composição musical.

Há ainda outros motivos que fazem do canto coral uma atividade adequada para a musicalização no teatro.

O primeiro é o fato de ser uma atividade de grupo, indo assim ao encontro da natureza coletiva do trabalho teatral. A música coral depende de um acordo sonoro coletivo para acontecer (ainda que para produzir um único som em uníssono, mas que jamais poderia ser produzido por um só indivíduo).

O segundo é o fato de a música coral se apoiar basicamente na produção sonora do corpo humano; seu material de trabalho é, portanto, o mesmo que o do ator.

Um terceiro motivo é justamente a relativa facilidade com que se pode dominar o instrumento vocal no canto coral (acrescido da segurança proporcionada pelo grupo), abrindo a possibilidade de se trabalhar a improvisação musical num contexto que favorece a interseção com eventuais propostas de improvisação teatral.

É obrigatório ressaltar que a idéia de coro aqui proposta envolve essa vontade de unir as experiências musical e teatral, sugerindo uma atuação coral ampliada para as ações do corpo e da voz no espaço - características necessárias da formação do ator.

\section{0 ator, o espectador e a escuta: uma pedagogia da escuta}

Uma abordagem musical da voz no teatro deve passar necessariamente pela questão da escuta. Todo aprendizado musical é, antes de tudo, um aprendizado da escuta; é a partir dela, justamente, que surgirá uma intencionalidade vocal e se organizará uma reação sonora através da voz. É, portanto, fundamental que o trabalho de musicalização do ator se apóie em uma pedagogia da escuta - a qual deve ser pensada com amplitude, assim como o conceito de canto coral.

Essa voz se organiza também em função de um ouvinte - ou de um espectador. Este fato amplia ainda mais essa concepção de escuta, e nos leva à necessidade de pensar os meios pelos quais isso se dará.

\section{Estado e sentimento; liberação e espontaneidade}

A adequação vocal na prática coral que estamos propondo é alcançada, basicamente, através de propostas que buscam a disponibilidade corporal em relação aos objetivos expressivos, acreditando que ela é a condição primeira e a mais importante para que se chegue a uma produção vocal de qualidade - qualidade medida pela adequação vocal de cada participante e do grupo como um todo.

Isso quer dizer que é exatamente a compreensão do sentido musical (na qual se inclui, por exemplo, a percepção de estruturas de composição e dos gestos musicais) que promove a intencionalidade do cantor numa direção expressiva determinada, o que motiva a organização corporal, portanto vocal, para uma consecução poética do objetivo musical, e não apenas mecânica.

É necessário, assim, que o trabalho de formação musical do ator através do coro proponha e se revista da sensibilidade adequada para que cada participante se disponibilize para caminhar em direção a esse estado físico-poético.

Todo esse trabalho inclui, evidentemente, o cuidado com a particularidade e a singularidade de cada voz. Deve haver um trabalho ponto a ponto com cada ator-cantor, na busca do desvelar pessoal de sua voz, enquanto simultaneamente se estabelecem relações dessa voz com a grande voz coletiva. 


\section{Conteúdos}

Neste caminho, ter um objetivo expressivo, uma intenção e a escuta foram propostos como guias para o trabalho vocal.

Alguns conteúdos musicais fundamentais devem ser trabalhados. No plano da percepção sonora, os parâmetros altura, timbre, intensidade e duração. No plano da linguagem, concei- tos como melodia, ritmo, harmonia, estrutura, forma, idéia musical, gesto musical, improvisação e composição.

É também útil perguntar-se o que podemos aprender, por exemplo, com nossa tradição musical, com a de outras culturas, com a paisagem sonora à nossa volta.

Podemos escutá-los...

E cantá-los. 